\title{
Association of morphological and water factors with irrigated forage cactus yield
}

\author{
Marcela L. Barbosa ${ }^{1}$, Thieres G. F. da Silva ${ }^{2}$, Sérgio Zolnier ${ }^{1}$, \\ Servulo M. S. e Silva ${ }^{3}$, José E. F. de Morais ${ }^{2} \&$ Mery C. de S. Assis ${ }^{2}$ \\ ${ }^{1}$ Universidade Federal de Viçosa/Departamento de Engenharia Agrícola. Viçosa, MG. E-mail: marcelalucia.ufrpe@gmail.com (Corresponding \\ author); zolnier@ufv.br \\ ${ }^{2}$ Universidade Federal Rural de Pernambuco/Unidade Acadêmica de Serra Talhada. Serra Talhada, PE. E-mail: thieres_freire@yahoo.com.br; \\ joseedson50@hotmail.com; mcsamenezes@gmail.com \\ ${ }^{3}$ Instituto Agronômico de Pernambuco. Arcoverde, PE. E-mail: servulo.siqueira@ipa.br
}

Key words:

evapotranspiration

Nopalea sp.

Opuntia sp.

Brazilian Semi-arid region

\begin{abstract}
A B S T R A C T
This study aimed to understand the relationship of morphological characteristics and actual evapotranspiration of forage cactus clones with their productive capacity under different water regimes. The data used in this study were collected between the years 2012 and 2013, in Serra Talhada, State of Pernambuco. The clones Sertânia IPA - IPA, Miúda - MIU and Orelha de Elefante Mexicana - OEM were submitted to three irrigation depths (2.5, 5.0 and $7.5 \mathrm{~mm}$ ) and three irrigation intervals (7, 14 and 28 days). Cladode and plant morphology, accumulated actual evapotranspiration and yield were obtained at the moment of harvest. Pearson's correlation matrix was elaborated and, in the sequence, multicollinearity, canonical and path analysis were applied. There was no correlation of yield with the soil water supply and actual evapotranspiration of the clones $(p>0.05)$. Forage cactus yield was more associated with peculiarities of the morphological characteristics of the clones than with the different soil water supplies or the crop actual evapotranspiration. However, regardless of the water regime and clone, the vigor of the basal cladodes was highly decisive for the expression of the forage cactus productive capacity.
\end{abstract}

\section{Palavras-chave:}

evapotranspiração

Nopalea sp.

Opuntia sp.

Semiárido brasileiro

\section{Associação de fatores morfológicos e hídricos com a produtividade da palma forrageira irrigada}

\section{R E S U M O}

Objetivou-se, neste trabalho, compreender a relação de características morfológicas e da evapotranspiração real de clones de palma forrageira com sua capacidade produtiva em diferentes regimes hídricos. Os dados usados nesta pesquisa foram coletados entre os anos de 2012 e 2013, em Serra Talhada, PE. Os clones IPA Sertânia - IPA, Miúda - MIU e Orelha de Elefante Mexicana - OEM foram submetidos a três lâminas $(2,5 ; 5,0$; e 7,5 mm) e três intervalos de irrigação ( $7 ; 14$ e 28 dias). Dados morfológicos dos cladódios e da planta, evapotranspiração real acumulada e desempenho produtivo foram obtidos na ocasião da colheita. A matriz de correlação de Pearson foi elaborada e, em seguida, foram aplicadas análises de multicolinearidade, canônica e de trilha. Não houve correlação da produtividade com o suprimento de água e evapotranspiração real dos clones $(\mathrm{p}>0,05)$. A produtividade da palma esteve mais associada a peculiaridades das características morfológicas dos seus clones do que aos diferentes suprimentos de água no solo ou à evapotranspiração real da cultura. Mas, independente do regime hídrico e do clone, o vigor do cladódio basal foi bastante decisivo para a expressão da capacidade produtiva da palma forrageira irrigada. 


\section{INTRODUCTION}

Forage cactus has different varieties belonging to the genera Opuntia and Nopalea, and, despite having the same photosynthetic process, the crassulacean acid metabolism (CAM), has characteristics that differentiate them, such as morphology and, thus, water use efficiency (Silva et al., 2014a, 2015).

Different from $\mathrm{C}_{3}$ and $\mathrm{C}_{4}$ plants, $\mathrm{CAM}$ species open their stomata at night to capture the $\mathrm{CO}_{2}$ necessary for their metabolism, which reduces water transfer to the atmosphere, i.e., evapotranspiration (ET). The ET varies between species, at the same time is affected by the crop management (Allen et al., 1998).

Studies conducted with forage cactus demonstrate that, although it tolerates extreme drought conditions, the application of supplementary irrigation events favors the productive performance, increasing the availability of food in semi-arid regions, especially in the drought period (FloresHernandez et al., 2004; Queiroz et al., 2015).

The contribution of morphological and environmental characteristics to the yield of forage cactus clones has been cited in the literature (Silva et al., 2010, 2015; Pinheiro et al., 2014), but it does not contemplate irrigated cultivation and does not meet water parameters, such as actual crop evapotranspiration.

Hence, the association of water-productive factors of the forage cactus planting system with morphological characteristics can establish new indicators of indirect selection of clones that are more productive and with higher water use efficiency for the different sites or that have wide interannual seasonality of rainfalls (Neder et al., 2013; Pinheiro et al., 2014).

This study aimed to understand the association of morphological and water factors of forage cactus clones with productive capacity under different water regimes.

\section{Material AND Methods}

Morphological, water and production data of forage cactus were collected in an experimental area (7० 56' $20^{\prime \prime}$ 'S; $38^{\circ} 17^{\prime} 31^{\prime \prime}$ W; $498 \mathrm{~m}$ ) of the Agronomic Institute of Pernambuco, in Serra Talhada, PE, Brazilian semi-arid region, conducted between the years 2012 and 2013. The soil of the area was classified as Red Yellow Argisol.

The studied clones were IPA-Sertânia - IPA (Napolea cochenillifera (L.) Salm. Dick), Miúda - MIU (Napolea cochenillifera (L.) Salm. Dick) and Orelha de Elefante Mexicana - OEM (Opuntia stricta (Haw.) Haw.) planted in February 2010 , at spacing of $1.6 \times 0.2 \mathrm{~m}$, with the crop rows along contour lines. The clones were arranged in a randomized block design, in $3 \times 3 \times 3+3$ factorial scheme, with three replicates, plus one control for each clone. Until March 2012, the clones were maintained under rainfed conditions, when plants were harvested, leaving only the basal cladode. From this date on, the data started to be collected for the present study, which ended in August 2013, totaling 532 days.

In this period, irrigation events were applied using a drip system (drippers spaced by $0.20 \mathrm{~m}$ ), adopting three fixed water depths (L) for water replacement $(2.5,5.0$ and $7.5 \mathrm{~mm}$, plots) with three frequencies (F) (7, 14 and 28 days, subplots). The three clones (IPA, MIU and OEM) formed the sub-subplots. Each one was composed of four rows of 20 plants, with total area of $25.6 \mathrm{~m}^{2}$ and evaluation area of $11.52 \mathrm{~m}^{2}$. Cultivation practices were performed along the vegetative cycle of the crop.

Irrigation depths and frequencies were established based on information surveyed in areas of forage cactus producers of the Rio Grande do Norte state, which irrigated the crop with events of $5.0 \mathrm{~mm}$ every 14 days.

The three forage cactus clones received the equivalent to (water supply): 756 (L7.5 F7), 672 (L5.0 F7), 622 (L7.5 F14), 586 (L2.5 F7), 579 (L5.0 F14), 555 (L7.5 F28), 536 (L2.5 F14), 535 (L5.0 F28), 514 (L2.5 F28) and 493 (Control) mm year $^{-1}$.

At harvest, the measurements of the cladodes (CT thickness, CL- length, CW - width, CP - perimeter and CA cladode area per order of appearance: B - basal; 1 - first order; 2 - second order; 3 - third order) and of the plant (TNC - total number of cladodes of the plant per order of appearance NC1, NC2 and NC3, PH - height and PW - width of the plant, CAI - cladode area index) were obtained through biometric campaign. The adopted procedures were described in Pinheiro et al. (2014) and Silva et al. (2014b, 2015).

Subsequently, all plants of the evaluation area were harvested and weighed to determine the yield per sub-subplot. Five representative cladodes per sub-subplot were sampled to obtain the individual fresh biomass (CFB, g cladode ${ }^{-1}$ ) and, after that, for dry biomass $\left(\mathrm{CDB}, \mathrm{g}_{\text {cladode }} \mathrm{c}^{-1}\right)$, the cladodes were dried in an oven at $65^{\circ} \mathrm{C}$, until constant weight. The ratio between $\mathrm{CDB}$ and $\mathrm{CFB}$ generated the dry matter content (DMC, \%). The data of yield and final plant density were used to calculate the fresh matter yield (FMY, $\mathrm{t} \mathrm{ha}^{-1}$ ). The product between DMC and FMY resulted in dry matter yield (DMY, $\mathrm{t} \mathrm{ha}^{-1}$ ).

The actual evapotranspiration of the clones was calculated over time through the data of water content and physicalhydraulic properties of the soil, according to Silva et al. (2014a). In addition, the soil water balance (SWB) method was used for a control volume with depth of $0.70 \mathrm{~m}$, in intervals of 14 days $(\mathrm{ET}=\mathrm{P}+\mathrm{I} \pm \mathrm{Q} \pm \Delta \mathrm{WS}$, where $\mathrm{P}$ - pluviometric precipitation, I - irrigation, $Q$ - vertical water flow in the soil, represented by capillary rise and deep drainage, and $\Delta \mathrm{WS}$ - water storage variation in the soil, all in $\mathrm{mm}$ ).

The data of soil water content were monitored using a capacitive sensor (Diviner $2000^{\circ}$, Sentek Pty Ltda., Australia). This sensor was inserted in access tubes installed at depth of 0.90 and $0.10 \mathrm{~m}$ away from the crop row, in each sub-subplot. The sensor was calibrated locally, as described by Araújo Primo et al. (2015).

ET values were related to the data of reference evapotranspiration (ETo) to obtain the ET/ETo ratio. ETo was estimated through the Penman-Monteith method (Allen et al., 1998), using meteorological data of an automatic station of the National Institute of Meteorology - INMET, situated close to the area. At the end of the cycle, ET values were integrated ( $\left.\sum \mathrm{ET}\right)$.

All data were subjected to the Lilliefors test, to verify normality, and subdivided into four groups: plant morphology 
- "Plant" (PH, PW, TNC, NC1, etc.); Cladode morphology "Cladodes" (CLB, CL1, CL2, etc.); evapotranspiration "ET" (ET and ET/ETo) and "YIELD" (CFB, CDB, FMY, DMY and DMC). The latter was considered as response group and the others as explicative groups.

The response variables ("YIELD") were correlated with the explicative variables ("Plant", "Cladodes" and "ET"), through the Pearson's correlation matrix (Cunha et al., 2011). Subsequently, multicollinearity test was applied to the data to detect if the variables within the same group were highly correlated. Then, variables that fitted this condition were removed from the data set as suggested by Toebe \& Cargnelutti Filho (2013). Lastly, canonical analysis was applied to evaluate the association between explicative and response groups, and path analysis was applied, in the partitioning of the Pearson's correlation coefficient, to identify its direct and indirect effects (Cunha et al., 2011). The significance of the partial correlation was made through the chi-square test, at 0.01 probability level. All analyses were made in the statistical program "GENES" (Cruz, 2006).

\section{Results AND Discussion}

There was no correlation of water supply and actual evapotranspiration of forage cactus (ET and ET/ETo) with crop yield $(p>0.05)$.

The increment of forage cactus production did not respond directly to the increase in soil water supply, which varied between 493 and $756 \mathrm{~mm}$ year ${ }^{-1}$. Hence, the morphological indicators of identification of the most productive clones are not dependent on the water regime of the cultivation environment.

Flores-Hernandez et al. (2004) and Queiroz et al. (2015), applying increasing water depths from 760 to $1380 \mathrm{~mm}_{\text {year }}{ }^{-1}$ and from 976 to $1202 \mathrm{~mm}_{\text {year }}{ }^{-1}$, respectively, also did not find response of forage cactus production. Queiroz et al. (2015) cite that, under full water availability, the immediate response of the forage cactus may not be observed due to its high capacity of water storage in the cladodes, low water demand and reduced conversion into dry matter. Thus, Scalisi et al. (2016) suggest that controlled reductions in the irrigation depths may not affect the biomass of the plants.

The ET of the clones showed no correlation with their yields, which is justified by the crassulacean mechanism of forage cactus, which, besides minimizing transpiration, increases the importance of the evaporation component (Han \& Felker, 1997) so that the increment in ET does not increase yield proportionally.

The morphological factors showed the highest correlation with the productive expression of the clones.

Significant correlation coefficients for the clones IPA and OEM were obtained of the production variables (IPA: DMY, DMC and CFB; OEM: DMY, DMC, CFB and CDB) with plant morphology (IPA: PW, NC2 and NC3; OEM: PW, NC1 and NC2) and cladode morphology (IPA: CL2, CTB, CT3 and CP2; OEM: CLB, CL1, CW1, CTB, CT2 and CAB). Thus, canonical analysis was applied between these groups, per clone (IPA and OEM).
Only one production variable of the MIU showed correlation with $\mathrm{PH}$ and cladode morphology (CLB, CL2, CPB and $\mathrm{CAB}$ ). Thus, the association between the groups "YIELD" and "Plant" was not evaluated and there was no significant canonical axis between the groups "YIELD" and "Cladode".

The association between the groups "YIELD" and "Cladode" (Table 1) of IPA demonstrated that plants with higher CTB and of third-order showed higher CFB, but in detriment of DMC. There was no significant canonical axis with the group "Plant", indicating that "YIELD" is independent of this group and the effects of their variables occurred separately.

For OEM (Table 1), two canonical axes were significant in the association between the groups "YIELD" and "Plant", and there was no correlation with the group "Cladode".

In the first axis, the highest DMY and DMC occurred in plants with greater dimensions of the basal cladodes (CAB). However, in this condition, there was a reduction in $\mathrm{CFB}$ and $\mathrm{CDB}$, when plants with larger basal cladodes (CLB, CAB) also had greater dimensions of the first-order cladode (CL1), according to the second axis $\left(0.994^{\star}\right)$.

In the partitioning of the correlation coefficients through the path analysis, the NC3 showed the highest positive explanation for the CFB of IPA (Table 2), with direct and indirect effect (via NC2), followed by PW, explaining together $60.7 \%$ of its variability. In terms of cladode, the perimeter of those of second-order (CP2) contributed to the increment in DMY, reaching $60.3 \%$.

In turn, the accumulation of CFB was favored in plants with larger second-order cladodes and thicker third-order cladodes,

Table 1. Canonical correlations between the groups "YIELD" and "Cladode" of IPA Sertânia (IPA) and "YIELD" and "Plant" of Orelha de Elefante Mexicana (OEM)

\begin{tabular}{|c|c|c|c|c|c|}
\hline \multirow{2}{*}{ Groups } & \multirow{2}{*}{ Variables } & \multicolumn{4}{|c|}{ Canonical factors } \\
\hline & & $1^{\circ}$ & $2^{\circ}$ & $3^{\circ}$ & $4^{\circ}$ \\
\hline \multicolumn{6}{|c|}{ IPA Sertânia } \\
\hline \multirow{3}{*}{ I - Yield } & DMY & 0.013 & 0.850 & -0.526 & - \\
\hline & DMC & -0.721 & 0.034 & 0.692 & - \\
\hline & CFB & 0.716 & 0.694 & -0.081 & - \\
\hline \multirow{4}{*}{ II - Cladode } & CL2 & 0.431 & 0.833 & -0.260 & - \\
\hline & CTB & 0.743 & 0.131 & -0.633 & - \\
\hline & CT3 & 0.801 & 0.433 & 0.334 & - \\
\hline & CP2 & 0.004 & 0.704 & -0.703 & - \\
\hline \multicolumn{2}{|c|}{ CC } & 0.995 ** & 0.893 & 0.311 & - \\
\hline \multirow{2}{*}{\multicolumn{2}{|c|}{$\begin{array}{c}\chi^{2} \\
D F\end{array}$}} & 31 & 8 & 1 & - \\
\hline & & 12 & 6 & 2 & - \\
\hline \multicolumn{6}{|c|}{ Orelha de Elefante Mexicana } \\
\hline \multirow{4}{*}{ I - Yield } & DMY & 0.569 & 0.266 & 0.236 & -0.741 \\
\hline & DMC & 0.539 & -0.167 & -0.589 & 0.578 \\
\hline & CFB & -0.402 & 0.651 & 0.496 & -0.411 \\
\hline & CDB & 0.091 & 0.846 & -0.477 & -0.220 \\
\hline \multirow{6}{*}{ II - Plant } & CLB & 0.202 & -0.522 & 0.775 & 0.178 \\
\hline & CL1 & -0.239 & -0.769 & 0.543 & 0.065 \\
\hline & CW1 & -0.177 & 0.302 & 0.781 & -0.471 \\
\hline & CTB & 0.223 & -0.311 & 0.178 & -0.875 \\
\hline & CT2 & 0.154 & 0.059 & 0.649 & -0.607 \\
\hline & $\mathrm{CAB}$ & 0.389 & -0.583 & 0.541 & 0.244 \\
\hline \multicolumn{2}{|c|}{ CC } & 0.999* & $0.994^{*}$ & 0.951 & 0.849 \\
\hline \multicolumn{2}{|l|}{$\chi^{2}$} & 76 & 28 & 13 & 4 \\
\hline \multicolumn{2}{|l|}{$\mathrm{DF}$} & 24 & 15 & 8 & 3 \\
\hline
\end{tabular}

DMY - Dry matter yield, DMC - Dry matter content, CFB, CDB - Cladode fresh and dry biomass CLB, CL1, CL2 - Length of basal, first- and second-order cladodes, CW1 - Width of firstorder cladode, CTB, CT2, СT3 - Thickness of basal, second- and third-order cladodes, CP2 - Perimeter of second-order cladode, CAB - Area of basal cladode. ** * Significant at 0.01 and 0.05 , respectively, by Chi-square test; CC - Canonical correlation, DF - Degrees of freedom 
Table 2. Partitioning of the correlation coefficient in direct and indirect effects between the variables of the groups "YIELD", "Plant" and "Cladode" of IPA Sertânia (IPA)

\begin{tabular}{|c|c|c|c|c|}
\hline Variable & Effect & DMY & DMC & CFB \\
\hline \multicolumn{5}{|c|}{ “Plant" Group } \\
\hline \multirow{4}{*}{ PW } & Direct effect PW & - & - & 0.303 \\
\hline & Indirect effect via NC2 & - & - & 0.127 \\
\hline & Indirect effect via NC3 & - & - & 0.284 \\
\hline & Total & - & - & 0.714 \\
\hline \multirow{4}{*}{ NC2 } & Direct effect NC2 & - & - & 0.149 \\
\hline & Indirect effect via PW & - & - & 0.258 \\
\hline & Indirect effect via NC3 & - & - & 0.298 \\
\hline & Total & - & - & 0.705 \\
\hline \multirow{5}{*}{ NC3 } & Direct effect NC3 & - & - & 0.393 \\
\hline & Indirect effect via PW & - & - & 0.220 \\
\hline & Indirect effect via NC2 & - & - & 0.113 \\
\hline & Total & - & - & 0.725 \\
\hline & $\mathrm{R}^{2}$ & - & - & 0.607 \\
\hline \multicolumn{5}{|c|}{ "Cladode" Group } \\
\hline \multirow{5}{*}{ CL2 } & Direct effect CL2 & 0.324 & - & 0.455 \\
\hline & Indirect effect via CTB & -0.278 & - & 0.084 \\
\hline & Indirect effect via CT3 & 0.138 & - & 0.293 \\
\hline & Indirect effect via CP2 & 0.496 & - & -0.003 \\
\hline & Total & 0.680 & - & 0.829 \\
\hline \multirow{5}{*}{ CTB } & Direct effect CTB & - & -0.746 & - \\
\hline & Indirect effect via CL2 & - & 0.109 & - \\
\hline & Indirect effect via CT3 & - & -0.118 & - \\
\hline & Indirect effect via CP2 & - & 0.090 & - \\
\hline & Total & - & -0.665 & - \\
\hline \multirow{5}{*}{ CT3 } & Direct effect CT3 & - & - & 0.522 \\
\hline & Indirect effect via CL2 & - & - & 0.256 \\
\hline & Indirect effect via CTB & - & - & 0.053 \\
\hline & Indirect effect via CP2 & - & - & 0.000 \\
\hline & Total & - & - & 0.830 \\
\hline \multirow{6}{*}{$\mathrm{CP} 2$} & Direct effect CP2 & 0.625 & - & - \\
\hline & Indirect effect via CL2 & 0.257 & - & - \\
\hline & Indirect effect via CTB & -0.245 & - & - \\
\hline & Indirect effect via CT3 & 0.012 & - & - \\
\hline & Total & 0.650 & - & - \\
\hline & $\mathrm{R}^{2}$ & 0.603 & 0.561 & 0.891 \\
\hline
\end{tabular}

DMY - Dry matter yield, DMC - Dry matter content, CFB - Cladode fresh biomass; PW - Plant width, NC2, NC3 - Number of second- and third-order cladodes; CL2 - Length of second-order cladode, CTB, CT3 - Thickness of basal and third-order cladodes, CP2 - Perimeter of secondorder cladode. "-" Indicates that there was correlation between the variables

responsible for $89.1 \%$. Basal cladodes with greater thickness resulted in plants with lower DMC.

For the clone IPA, the contribution of the number of third-order cladodes to the increment in fresh biomass may be related to the greater capture of $\mathrm{CO}_{2}$, compared with those of lower orders (Liguori et al., 2013). In turn, plant width has been cited as good variable to be adopted in the selection of more-productive clones (Silva et al., 2010; Pinheiro et al., 2014).

For the clone Miúda, the highest DMY occurred in taller plants and was related to basal cladodes with larger areas (Table 3), either through direct or indirect effect (via CLB, CL2, CPB). These cladodes explained $88.7 \%$ of the variation in DMY. Larger basal cladodes are fundamental to guarantee plant support, since MIU has higher number of cladodes in comparison to IPA and OEM (Silva et al., 2015). Nevertheless, Cavalcante et al. (2014) highlight that MIU has lower biomass accumulation compared with the Opuntia clones.

The highest yield of OEM (DMY) was observed in plants with higher number and thickness of second-order cladodes (NC2 and CT2) and thicker basal cladodes (CTB) (Tables 4 and 5). Thus, there were increments in DMC and decrease in
Table 3. Partitioning of the correlation coefficient in direct and indirect effects between the variables of the groups "YIELD" and "Cladode" of Miúda (MIU)

\begin{tabular}{clr}
\hline Variable & \multicolumn{1}{c}{ Effect } & DMY \\
& Direct effect CLB & -0.082 \\
CLB & Indirect effect via CL2 & 0.151 \\
& Indirect effect via CPB & -0.265 \\
& Indirect effect via CAB & 0.926 \\
& Total & 0.730 \\
& Direct effect CL2 & 0.193 \\
CL2 & Indirect effect via CLB & -0.064 \\
& Indirect effect via CPB & -0.215 \\
& Indirect effect via CAB & 0.735 \\
& Total & 0.648 \\
CPB & Direct effect CPB & -0.279 \\
& Indirect effect via CLB & -0.078 \\
& Indirect effect via CL2 & 0.149 \\
& Indirect effect via CAB & 0.887 \\
& Total & 0.678 \\
CAB & Direct effect CAB & 1.092 \\
& Indirect effect via CLB & -0.070 \\
& Indirect effect via CL2 & 0.130 \\
\hline Determination coefficient & Indirect effect via CPB & -0.227 \\
\hline
\end{tabular}

DMY - Dry matter yield; CLB, CL2 - Length of basal and second-order cladodes, CPB Perimeter of basal cladode, CAB - Area of basal cladode

Table 4. Partitioning of the correlation coefficient in direct and indirect effects between the variables of the groups "YIELD" and "Plant" of Orelha de Elefante Mexicana (OEM)

\begin{tabular}{clcccc}
\hline Variable & \multicolumn{1}{c}{ Effect } & DMY & DMC & CFB & CDB \\
& Direct effect PW & 0.211 & - & - & - \\
\multirow{5}{*}{ PW } & Indirect effect via NC1 & -0.002 & - & - & - \\
& Indirect effect via NC2 & 0.452 & - & - & - \\
& Total & 0.661 & - & - & - \\
\multirow{5}{*}{ NC1 } & Direct effect NC1 & - & - & - & 0.726 \\
& Indirect effect via PW & - & - & - & -0.005 \\
& Indirect effect via NC2 & - & - & - & -0.037 \\
& Total & - & - & - & 0.684 \\
& Direct effect NC2 & 0.571 & - & - & - \\
\multirow{5}{*}{ NC2 } & Indirect effect via PW & 0.167 & - & - & - \\
& Indirect effect via NC1 & 0.031 & - & - & - \\
& Total & 0.769 & - & - & - \\
Determination coefficient & 0.612 & - & - & 0.500 \\
\hline
\end{tabular}

DMY - Dry matter yield, DMC - Dry matter content, CFB, CDB - Cladode fresh and dry biomass; PW - Plant width, NC1, NC2 - Number of first- and second-order cladodes; "-" Indicates that there was correlation between the variables

$\mathrm{CFB}$, associated with lower first-order cladodes (CW1). Hence, the morphological characteristics of second-order cladodes and vigor of the basal cladode had the highest contributions to the yield of OEM.

Second-order cladodes are those in higher number in the clone OEM; thus, they contribute more to the final crop yield. On the other hand, the growth of these cladodes is expected to result in reduction of the dimensions of lower cladodes. Silva et al. (2010), in study conducted with 50 clones, observed that the basal and first-order cladodes showed the largest morphological dimensions since they support the plant; however, proportional reductions of these dimensions were observed with the appearance of cladodes of higher orders.

Regardless of the clone, the vigor of the basal cladode was determinant for crop yield. Pimienta-Barrios et al. (2005) observed decrease in the daily gain of $\mathrm{CO}_{2}$ and reduction in the relative water content of these cladodes in dry periods, indicating water 
Table 5. Partitioning of the correlation coefficient in direct and indirect effects between the variables of the groups "YIELD" and "Cladode" of Orelha de Elefante Mexicana (OEM)

\begin{tabular}{|c|c|c|c|c|c|}
\hline Variable & Effect & DMY & DMC & CFB & CDB \\
\hline \multirow{7}{*}{ CLB } & Direct effect CLB & - & - & - & -0.383 \\
\hline & Indirect effect via CL1 & - & - & - & -0.554 \\
\hline & Indirect effect via CW1 & - & - & - & 0.064 \\
\hline & Indirect effect via CTB & - & - & - & -0.023 \\
\hline & Indirect effect via CT2 & - & - & - & 0.040 \\
\hline & Indirect effect via CAB & - & - & - & 0.051 \\
\hline & Total & - & - & - & -0.805 \\
\hline \multirow{7}{*}{ CL1 } & Direct effect CL1 & - & - & - & -0.757 \\
\hline & Indirect effect via CLB & - & - & - & -0.281 \\
\hline & Indirect effect via CW1 & - & - & - & 0.044 \\
\hline & Indirect effect via CTB & - & - & - & -0.016 \\
\hline & Indirect effect via CT2 & - & - & - & 0.035 \\
\hline & Indirect effect via CAB & - & - & - & 0.049 \\
\hline & Total & - & - & - & -0.926 \\
\hline \multirow{7}{*}{ CW1 } & Direct effect CW1 & - & -0.765 & 0.884 & - \\
\hline & Indirect effect via CLB & - & 0.014 & 0.004 & - \\
\hline & Indirect effect via CL1 & - & -0.133 & 0.003 & - \\
\hline & Indirect effect via CTB & - & 0.005 & -0.129 & - \\
\hline & Indirect effect via CT2 & - & -0.018 & 0.101 & - \\
\hline & Indirect effect via $\mathrm{CAB}$ & - & 0.083 & -0.065 & - \\
\hline & Total & - & -0.815 & 0.799 & - \\
\hline \multirow{7}{*}{ CTB } & Direct effect CTB & 0.452 & - & - & - \\
\hline & Indirect effect via CLB & -0.009 & - & - & - \\
\hline & Indirect effect via CL1 & -0.148 & - & - & - \\
\hline & Indirect effect via CW1 & 0.025 & - & - & - \\
\hline & Indirect effect via CT2 & 0.267 & - & - & - \\
\hline & Indirect effect via CAB & 0.048 & - & - & - \\
\hline & Total & 0.635 & - & - & - \\
\hline \multirow{7}{*}{ CT2 } & Direct effect CT2 & 0.456 & - & - & - \\
\hline & Indirect effect via CLB & -0.012 & - & - & - \\
\hline & Indirect effect via CL1 & -0.247 & - & - & - \\
\hline & Indirect effect via CW1 & 0.044 & - & - & - \\
\hline & Indirect effect via CTB & 0.265 & - & - & - \\
\hline & Indirect effect via $\mathrm{CAB}$ & 0.125 & - & - & - \\
\hline & Total & 0.630 & - & - & - \\
\hline \multirow{7}{*}{ CAB } & Direct effect CAB & - & - & - & 0.066 \\
\hline & Indirect effect via CLB & - & - & - & -0.298 \\
\hline & Indirect effect via CL1 & - & - & - & -0.559 \\
\hline & Indirect effect via CW1 & - & - & - & 0.026 \\
\hline & Indirect effect via CTB & - & - & - & -0.008 \\
\hline & Indirect effect via CT2 & - & - & - & 0.028 \\
\hline & Total & - & - & - & -0.746 \\
\hline \multicolumn{2}{|c|}{ Determination coefficient } & 0.840 & 0.873 & 0.924 & 0.956 \\
\hline
\end{tabular}

DMY - Dry matter yield, DMC - Dry matter content, CFB, CDB - Cladode fresh and dry biomass; CLB, CL1 - Length of basal and first-order cladodes, CW1 - Width of first-order cladode, CTB, CT2 - Thickness of basal and second-order cladodes, CAB - Area of basal cladode. "-" Indicates that there was correlation between the variables

movement to the cladodes above. Thus, besides the function of support, basal cladodes become source of water and maintenance of the plant photosynthetic activity in drought periods.

\section{Conclusions}

1. The yield of forage cactus cultivated under water regimes from 493 to $756 \mathrm{~mm}$ year ${ }^{-1}$ was more associated with the peculiarities of the morphological characteristics of its clones than with different water supplies or actual evapotranspiration.

2. The increase in water supply from 493 to $756 \mathrm{~mm}_{\text {year }}{ }^{-1}$ did not promote significant increment of production for the forage cactus.

3. Regardless of water regime and clone, the vigor of the basal cladode was highly decisive for the expression of the productive capacity of irrigated forage cactus.

\section{Acknowledgments}

To the Pernambuco Science and Technology Support Foundation (FACEPE), for the financial aid (APQ-02155.01/10) and to the Coordination for the Improvement of Higher Education Personnel (CAPES), for the scholarship.

\section{Literature Cited}

Allen, R. G.; Pereira, L. S.; Raes, D.; Smith, M. Crop evapotranspiration: Guidelines for computing crop water requirements. Rome: FAO, 1998. 301p.

Araújo Primo, J. T. de; Silva, T. G. F. da; Silva, S. M. S. e; Moura, M. S. B. de; Souza, L. S. B. de. Calibração de sondas capacitivas, funções físico-hídricas e variação do armazenamento de água em um argissolo cultivado com palma forrageira. Revista Ceres, v.62, p.20-29, 2015. https://doi.org/10.1590/0034-737X201562010003

Cavalcante, L. A. D.; Santos, G. R. de A.; Silva, L. M. da; Fagundes, J. L.; Silva, M. A. da. Respostas de genótipos de palma forrageira a diferentes densidades de cultivo. Pesquisa Agropecuária Tropical, v.44, p.424-433, 2014. https://doi.org/10.1590/S198340632014000400010

Cruz, C. D. Programa Genes: Biometria. Viçosa: UFV, 2006. 382p.

Cunha, M. V. da; Lira, M. de A.; Santos, M. V. F. dos; Freitas, E. V. de; Dubeux Júnior, J. C. B.; Mello, A. C. L. de; Martins, K. G. R. Association between the morphological and productive characteristics in the selection of elephant grass clones. Revista Brasileira de Zootecnia, v.40, p.482-488, 2011. https://doi. org/10.1590/S1516-35982011000300004

Flores-Hernández, A.; Orona-Castillo, I.; Murillo-Amador, B.; GarcíaHernández, J. L.; Troyo-Dieguez, E. Yield and physiological traits of prickly pear cactus 'nopal' (Opuntia spp.) cultivars under drip irrigation. Agricultural Water Management, v.70, p.97-107, 2004. https://doi.org/10.1016/j.agwat.2004.06.002

Han, H.; Felker, P. Field validation of water-use efficiency of the CAM plant Opuntia ellisiana in south Texas. Journal of Arid Environments, v.36, p.133-148, 1997. https://doi.org/10.1006/ jare.1996.0202

Liguori, G.; Inglese, G.; Pernice, F.; Sortino, G.; Inglese, P. $\mathrm{CO}_{2}$ uptake of Opuntia ficus-indica (L.) Mill. whole trees and single cladodes, in relation to plant water status and cladode age. Italian Journal Agronomy, v.8, p.14-20, 2013. https://doi.org/10.4081/ija.2013.e3

Neder, D. G.; Costa, F. R. da; Edvan, R. L.; Souto Filho, L. T. Correlations and path analysis of morphological and yield traits of cactus pear accessions. Crop Breeding Applied Biotechnology, v.13, p.203-207, 2013. https://doi.org/10.1590/S1984-70332013000300009

Pimienta-Barrios, E.; Zañudo-Hernandez, J.; Rosas-Espinoza, V. C.; Valenzuela-Tapia, A.; Nobel, P. S. Young daughter cladodes affect $\mathrm{CO}_{2}$ uptake by mother cladodes of Opuntia ficus-indica. Annals of Botany, v.95, p.363-369, 2005. https://doi.org/10.1093/aob/mci034

Pinheiro, K. M.; Silva, T. G. F. da; Carvalho, H. F. de S.; Santos, J. E. O.; Morais, J. E. F. de; Zolnier, S.; Santos, D. C. dos. Correlações do índice de área do cladódio com características morfogênicas e produtivas da palma forrageira. Pesquisa Agropecuária Brasileira, v.49, p.939-947, 2014. https://doi.org/10.1590/S0100-204X2014001200004

Queiroz, M. G. de; Silva, T. G. F. da; Zolnier, S.; Silva, S. M. S. e; Lima, L. R.; Alves, J. de O. Características morfofisiológicas e produtividade da palma forrageira sob diferentes lâminas de irrigação. Revista Brasileira de Engenharia Agrícola e Ambiental, v.19, p.931-938, 2015. https://doi.org/10.1590/1807-1929/ agriambi.v19n10p931-938 
Scalisi, A.; Morandi, B.; Inglese, P.; Bianco, R. L. Cladode growth dynamics in Opuntia ficus-indica under drought. Environmental and Experimental Botany, v.122, p.158-167, 2016. https://doi. org/10.1016/j.envexpbot.2015.10.003

Silva, N. G. de M. e; Lira, M. de A.; Santos, M. V. F. dos; Dubeux Júnior, J. C. B.; Mello, A. C. L. de; Silva, M. da C. Relação entre características morfológicas e produtivas de clones de palmaforrageira. Revista Brasileira de Zootecnia, v.39, p.2389-2397, 2010. https://doi.org/10.1590/S1516-35982010001100011

Silva, T. G. F. da; Araújo Primo, J. T. de; Morais, J. E. F. de; Diniz, W. J. da S; Souza, C. A. A.; Silva, M. da C. Crescimento e produtividade de clones de palma forrageira no semiárido e relações com variáveis meteorológicas. Revista Caatinga, v.28, p.10-18, 2015.
Silva, T. G. F. da; Araújo Primo, J. T. de; Silva, S. M. S. e; Moura, M. S. B. de; Santos, D. C. dos; Silva, M. da C.; Araújo, J. E. M. Indicadores de eficiência do uso da água e de nutrientes de clones de palma forrageira em condições de sequeiro no Semiárido brasileiro. Bragantia, v.73, p.184-191, 2014a. https://doi.org/10.1590/brag.2014.017

Silva, T. G. F. da; Miranda, K. R.; Santos, D. C. dos; Queiroz, M. G. de; Silva, M. da C.; Cruz Neto, J. F.; Araújo, J. E. M. Área do cladódio de clones de palma forrageira: Modelagem, análise e aplicabilidade. Revista Brasileira de Ciências Agrárias, v.9, p.633641, 2014b. https://doi.org/10.5039/agraria.v9i4a4553

Toebe, M.; Cargnelutti Filho, A. Não normalidade multivariada e multicolinearidade na análise de trilha em milho. Pesquisa Agropecuária Brasileira, v.48, p.466-477, 2013. https://doi. org/10.1590/S0100-204X2013000500002 